\title{
TOWARD A FEDERAL CIVIL INTERLOCUTORY APPEALS ACT
}

\author{
Paul D. Carrington*
}

"No verbal formula yet devised can explain prior finality decisions with unerring accuracy or provide an utterly reliable guide for the future." Surely this is so. If the federal experience alone did not suffice to convince us that this is true, then the comparisons provided in the preceding articles of this issue surely lay the matter to final rest. While jurisdiction after jurisdiction can be found to have embraced the wisdom that "causes should not come up here in fragments, upon successive appeals," 2 none has been discussed which has found that wisdom to be a simple one to be forthrightly applied. With varying degrees of candor and sophistication, each has hedged the finality requirement with exceptions and qualifications necessitated by shared perceptions that there are times when forthright application of a simple rule against piecemeal appeals works injustice and diseconomy.

There is a unifying theme to the occasions which have resulted in the breakdown of the stricture against piecemeal appeals which is observed repeatedly in the Interlocutory Restatement on the subject which the editors presented in the previous issue of this publication. ${ }^{3}$ It is that substantial rights, generally adjective in nature, are often threatened by the nonfinal actions of trial courts. And these rights cannot always be adequately protected by the courts of appeals if they await final decision to attempt corrective action. Hence comes the widespread use of the extraordinary writs as an alternative to appeal. Hence comes the collateral order doctrine. Hence comes the doctrine of practical finality, of death knells, and more. Similar considerations have prompted similar accommodations in each of the jurisdictions we have studied.

It does not follow from these considerations that the constraints against piecemeal appeals are a bad idea. Edson Sunderland, it is true, did once contend that the making of exceptions to the rule was pernicious, that once its simplicity is violated, it would occasion so much dispute that its benefits would not be worth its costs. ${ }^{4}$ While the federal experience may tend in some minds to confirm Professor Sunderland's assessment, the prevailing wisdom is that moderation in these matters is appropriate. Moderation, however, does not excuse the unconscionable

Copyright $\odot 1984$ by Law and Contemporary Problems

* Dean and Professor of Law, Duke University School of Law.

1. Eisen v. Carlisle \& Jacquelin, 417 U.S. 156, 170 (1974).

2. Canter v. American Ins. Co. 28 U.S. 307,318 (1830).

3. Federal Civil Appellate Jurisdiction: An Interlocutory Restatement, LAW \& CONTEMP. Probs., Spring 1984, at 1 .

4. Sunderland, The Problem of Appellate Review, 5 TEx. L. REv. 126, 127 (1926). 
intricacy of the existing law, depending as it does on overlapping exceptions, each less lucid than the next.

A major obstacle to clarity and reform in the federal practice, and perhaps elsewhere, has been the reluctance of courts of appeals to be candid in acknowledging the nature and regularity of the exceptions being made. As ready as the courts of appeals are to use their jurisdiction to assure procedural regularity in the district courts, they are equally ready to disavow the full implications of their actions. This is manifested in almost every corner of the Interlocutory Restatement, where almost every exception is accompanied by a reaffirmation of the rule against piecemeal appeals. And not infrequently, as is most clearly exemplified by appeals from orders striking insufficient affidavits of bias, the courts of appeals deny their own power even as they exercise it. ${ }^{5}$

This ambivalence is doubtless the product of anxiety that candor will open the floodgates of civil appeals. But the game is up. At least it is my perception that the bar and the trial bench are generally cognizant that the doors of the courts of appeals are open to protect substantial rights that cannot be enforced on appeal after final decision. ${ }^{6}$ Only the innocent may be confused or misled by the rhetoric.

It is thus time for reform. Partly because the present thicket is of the courts' creation, and partly because its underpinning is in the sparse provisions of the Judicial Code, the reform must be legislative. What is needed is a statutory machete to trim off the excess elaboration which has grown to conceal the accommodations that have been made.

In order to suggest the nature of what should be done, I have tried my hand at the elevating work of statutory drafting. ${ }^{7}$ I do so in the modest expectation that much further improvement can be wrought by more skilled hands but also in the equally modest conviction that what is proposed below would be a substantial advance on the present state of the federal law.

\section{A Civil Interlocutory Appeals ACT}

This proposal is presented as four sections of the Judicial Code, two being revisions and two being new:

\section{1291. Final Decisions of District Courts}

(a) The courts of appeals (other than the Court of Appeals for the Federal Circuit) shall have exclusive jurisdiction of appeals from all final decisions of the district courts of the United States, the District Court for the District of the Canal Zone, the District Court of Guam, and the District Court of the Virgin Islands, except

(1) where direct review may be had in the Supreme Court pursuant to sections 1252 or 1253 of this title; or

5. Federal Civil Appellate Jurisdiction: An Interlocutory Restatement, supra note 3, \& 24, at 171-74.

6. See generally M. Redish, The Pragmatic Approach to Appealability in the Federal Courls, 75 Colum. L. ReV. 89 (1975).

7. See also Note, Toward a More Rational Final Judgment Rule: A Proposal to Amend 28 U.S.C. \$ /292, 67 GEO. L.J. 1025 (1979). 
(2) exclusive jurisdiction is vested in the Court of Appeals for the Federal Circuit under section 1295(a) of this title.

(b) Appellate jurisdiction under this section shall not vest until the final decision of a district court is set forth on a separate document, signed by the district judge or magistrate, manifesting the intent of the district court that proceedings in the case be thereby terminated save for the taxation of costs or enforcement proceedings, and entered on the docket of the district court.

(c) A decree in admiralty which determines the rights and liabilities of the parties is a final decision even if the proceedings with respect to property subject to the jurisdiction of the court may continue to a final decree. In other civil cases involving multiple claims or multiple parties, a partial final decision may be made in conformity with rules of court promulgated in accordance with section 2072 of this title.

\section{REVISER'S NOTES}

Subsection (a) is the former section 1291 with slight cosmetic modification: the word "exclusive" is inserted in the second line to replace the last sentence of the former section with change in meaning. Also, the two exceptions are now enumerated.

Subsection (b) is new. In describing the formalities of a final decision, the subsection merely sets forth the present requirements as stated in Interlocutory Restatement $\S 3$. It is, however, a change in the law to make these formalities a precondition to jurisdiction under this section. The effect of the change is to abolish the doctrine of practical finality, the collateral order doctrine, and all other exceptions to the final decision requirement which are disguised by the strained determinations that orders are "final" when they are not so intended by the district court. This is not a consequential change in the law, because orders formerly appealable under these opaque doctrines will be made appealable under the next section of this title. A benefit of this clarification is that it should reduce the frequency of uncertainty regarding the possible existence of an appealable final decision.

Subsection (c) is largely new, but effects no change in the law. The first sentence preserves the appealability of orders previously treated as exceptional under section 1292(a)(3) of this title. The second sentence explicitly authorizes partial final decisions as prescribed in Rule 54 of the Federal Rules of Civil Procedure. Early doubt about the validity of that rule was resolved in Sears, Roebuck $\mathcal{G}^{\circ}$ Co. $v$. Mackey, 351 U.S. 427, 435-38 (1956); there appears to be no reason, however, why the existence of that rule should not be signalled in the statute to which it applies. See generally Interlocutory Restatement $\S 4$.

\section{\$ 1292. Interlocutory Decisions of District Courts}

(a) The courts of appeals shall have jurisdiction of appeals from interlocutory orders of the district courts when essential to protect substantial rights which cannot be effectively enforced on review after final decision. Interlocutory orders appealable under this subsection shall include those: 
(1) granting, continuing, modifying, refusing, or dissolving injunctions, or refusing to dissolve or modify injunctions, except where direct review may be had in the Supreme Court;

(2) appointing receivers or refusing to wind up receiverships or to take steps to accomplish the purposes thereof, such as directing the sales or other disposals of property;

(3) determining all issues in a civil action for patent infringement in form final except for an accounting; or

(4) designated as appealable orders by rule of court promulgated in accordance with section 2072 of this title.

(b) When a district court shall be of the opinion that an order involves a controlling question of law as to which there is a substantial ground for difference of opinion and that an immediate appeal from the order may materially advance the ultimate termination of the litigation, it shall so state in writing in such order. The Court of Appeals may thereupon, in its discretion, permit an appeal to be taken from such order.

(c) An appeal under this section shall be taken to the court of appeals which would have jurisdiction to review a final decision when entered, as provided in sections 1294 and 1295 of this title.

\section{REVISER'S NOTES}

The first sentence of subsection (a) is new. It is declaratory of existing practice, if not of existing doctrine. By authorizing interlocutory appeals when essential to protect substantial rights which cannot be effectively enforced on review after final decision, it eliminates the necessity for strained interpretations of finality under section 1291, and the use of extraordinary writs under section 1651 as an alternative to appeal. See Interlocutory Restatement $\S 12$. In making the statute conform to the realities of present federal practice, it is not intended to effect significant change in that practice. It is, however, possible that a few cases which might otherwise become embroiled in the intricacies of the collateral order doctrine or the uncertainties of mandamus law will be decided without regard to former technicalities. The effect of the reform should be to direct appellate courts and lawyers to the real considerations to be weighed in resolving issues of appellate jurisdiction, and to reduce the confusion that attends the present federal law. It will also eliminate the anomaly that presently exists with respect to the place of filing an interlocutory appeal. See Interlocutory Restatement $\S 13$.

Enumerated clauses (1) and (2) are not new, but simply preserve the existing legislation regarding appeals from preliminary injunction orders and receivership orders. The former provision of section 1292(a)(3) has been moved in this revision to section 1291(c). The new section 1292(a)(3) was section 1292(c)(2) being returned to its former location in section 1292(a).

Enumerated clause (4) is new and makes explicit that the rulemaking power does extend to the specification of appealable interlocutory decisions generally as defined in the first sentence of the subsection. It is contemplated that this rulemaking power may be used initially to clarify certain quiddities of the present 
established law, such as the astonishing rule with regard to appeals from orders granting or denying stays pending arbitration, see Interlocutory Restatement $\S 17$, or the rule denying appeals from orders directing civil arrest pending trial, see Interlocutory Restatement $\S 19$. This section is probably not necessary to validate such rules, cf. Sears, Roebuck $\mathcal{E}^{2}$ Co. v. Mackey, 351 U.S. 427, 435-38 (1956), but the use of the rulemaking power in this context is appropriately encouraged. There is no reason to conceal its existence from the reader of the controlling legislation.

Section 1292(b) remains, but with three clauses stricken. One ellipsis removes the requirement for certification that the order be one not otherwise appealable; a redundant certificate is harmless and there is no reason to require the trial court to appraise the limits of interlocutory appealability as a precondition to appealability. Another ellipsis imposed a ten day limitation period for applications for leave to appeal; all other limitations on appeals are expressed only in the Federal Rules of Appellate Procedure. This one is also expressed therein. Inasmuch as this revision explicitly approves such rulemaking, there seems to be no reason to preserve this particular limitation in the statute. The third ellipsis is the proviso that there shall be no stay pending appeal unless ordered by a judge; the only consequence of this proviso seems to be to preclude a magistrate from granting a stay and this consequence seems unintended since the language of the proviso antedates the existence of federal magistrates. The subject of stays is comprehensively controlled by Rule 8 of the Federal Rules of Appellate Procedure, and there is no apparent need for a specific statutory provision regarding stays pending certified interlocutory appeals.

Subsection (c) is new. It effects a change in authorizing certified interlocutory appeals under section 1292(b) to be taken to the United States Court of Appeals for the Federal Circuit in cases within the subject matter jurisdiction of that court. See Interlocutory Restatement § 2. It replaces former subsection (c)(1) which authorizes interlocutory appeals under section 1292(a) to be taken to the Federal Circuit. Former subsection (c) (2) has been returned in this revision to its former place in subsection (a).

The former subsection (d) is omitted from section 1292 because it pertains to orders of tribunals other than district courts. It is intended that this subsection be appended to section 1295 (not reprinted here) as section 1295(d). This is an appropriate location because the subsection pertains only to matters within the subject matter jurisdiction of the United States Court of Appeals for the Federal Circuit.

\section{\$ 1297. Time for Appeal}

The time for appeal under sections 1291, 1292, and 1293 may be limited by rule of court promulgated under section 2072 of this title. An appeal shall not be dismissed for untimeliness if the appellant did not receive notice of the adverse decision at the time at which the time for appeal commenced to run.

\section{REVISER'S NOTES}

This section is new.

The first sentence merely approves the present practice manifested in Rules 4 
and 5(d) of the Federal Rules of Appellate Procedure. The second sentence would change the law as stated in Interlocutory Restatement $\S 7$. The present law cannot be defended; it stands out as a unique situation in contemporary federal practice, for in no other instance can important rights be lost by mere passivity not involving neglect. It is, of course, rare that the notice which the clerk of court is directed to give is not given and received; but those rare cases which do occur result in unseemly harshness. A party favored by decision, who is concerned that the time for appeal be brought to an early termination, can protect himself against the risk of a failure of notice by taking the initiative of notifying the party against whom the decision was made.

\section{§ 1298. Jurisdictional Objections}

(a) A defect of appellate jurisdiction under sections 1291, 1292, 1293, and 1297, or rules of court promulgated pursuant to these sections, may be waived and appellate jurisdiction conferred by consent of the parties. Rules of court may be promulgated pursuant to section 2072 of this title which limit the time for making motions to dismiss appeals for unripeness or untimeliness.

(b) An otherwise timely appeal taken to the wrong court of appeals shall be transferred to the court of appeals designated by sections 1294, 1295, or 1292(c), whether or not any party seeks such a transfer.

\section{ReVISER's Notes}

This section is new.

Subsection (a) would result in a change in the law. The present law treats ripeness and timeliness as jurisdictional in the sense that they are objections that cannot be waived and must be raised by the court sua sponte. See Interlocutory Restatement $\S \S 6$ and 12 . This is a fetish which serves no significant systemic interest; the status and authority of the district court is scarcely threatened by the consideration of an appeal that is out of time. In this respect, the requirements of appellate jurisdiction are not unlike those of jurisdiction over the person or property of the civil defendant, which are subject to waiver under Rule 12(h) of the Federal Rules of Civil Procedure. By fixing time limits for the raising of such issues, the rules can require timely resolution of any issues regarding the ripeness or timeliness of an appeal. Belated presentation of such issues can be dilatory and inefficient.

Subsection (b) recognizes the quite different nature of the issue presented when an appeal which should go to the Federal Circuit is taken to a regional circuit, or vice versa. It is important to the attainment of the doctrinal stability which the Federal Circuit was organized to achieve that that court maintain the exclusivity of its jurisdiction. Hence the matter is more like the subject matter jurisdiction of the district courts which is not subject to waiver under Rule 12(h). There is, however, no reason to dismiss an appeal that is otherwise timely merely because the appellant has mistaken the court of appeals to which the appeal should be addressed. Compare section 1406 of this title. 